\title{
Correction: Family nurture intervention (FNI): methods and treatment protocol of a randomized controlled trial in the NICU
}

\author{
Martha G Welch ${ }^{1,2,3^{*}}$, Myron A Hofer ${ }^{1}$, Susan A Brunelli ${ }^{1}$, Raymond I Stark ${ }^{2}$, Howard F Andrews ${ }^{4}$, Judy Austin ${ }^{4}$, \\ Michael M Myers ${ }^{1,2,5}$ and FNI Trial Group ${ }^{1,2,5,6,}$
}

\section{Authors Correction:}

1 , \& Department of Psychiatry, College of Physicians \& Surgeons, 1051 Riverside Drive, Unit 40, New York, NY, 10032, USA

\section{Text correction:}

In our methods paper [1], we misstated the primary outcome variable, In addition, the power analyses on which the study Ns are based was not included in the article.

(1) The single primary outcome variable of our study design was Length of Stay (LOS), the number of days in the intensive care unit from day of birth to day of discharge home. All measures described in the paper as primary outcomes are secondary outcomes, including those outcomes listed in Tables 1 and 2.

(2)Previous studies that used LOS for evaluating interventions had total sample sizes of $\mathrm{N}=128,100$, and 28 , respectively [2-4]. To be conservative, we designated a total $\mathrm{N}=150$ to increase the prospect of statistical significance within a more acute population from our NICU (lower average birth weight and age) and to allow for attrition (including transfer to local level 2 NICUs). It was calculated that, for a significance level of alpha $=.05$, one hundred fifty infants would be sufficient to provide $80 \%$ power to detect a 5.3 day difference in length of hospital stay.

\footnotetext{
*Correspondence: mgw13@columbia.edu

'Department of Psychiatry, College of Physicians \& Surgeons, 1051 Riverside Drive, Unit 40, New York, NY 10032, USA

${ }^{2}$ Department of Pediatrics, College of Physicians \& Surgeons, 630 West 168th Street, New York, NY 10032, USA

Full list of author information is available at the end of the article
}

\begin{abstract}
Author details
'Department of Psychiatry, College of Physicians \& Surgeons, 1051 Riverside Drive, Unit 40, New York, NY 10032, USA. ${ }^{2}$ Department of Pediatrics, College of Physicians \& Surgeons, 630 West 168th Street, New York, NY 10032, USA. ${ }^{3}$ Department of Pathology \& Cell Biology, College of Physicians \& Surgeons, 630 West 168th Street, New York, NY 10032, USA. ${ }^{4}$ Mailman School of Public Health, Columbia University, 722 West 168th Street, New York, NY 10032,

USA. ${ }^{5}$ Department of Psychiatry, New York State Psychiatric Institute, 1051 Riverside Drive, New York, NY 10032, USA. ${ }^{6}$ Department of Psychology, Bronfman Science Center, Williams College, 18 Hoxsey Street, Williamstown, MA 01267, USA.
\end{abstract}

Received: 29 June 2012 Accepted: 25 July 2012

Published: 25 July 2012

\section{References}

1. Welch MG, Hofer MA, Brunelli SA, Stark RI, Andrews HF, Austin J, Myers MM, FNI Trial Group FN: Family nurture intervention (FNI): methods and treatment protocol of a randomized controlled trial in the NICU. BMC Pediatrics 2012, 12(1):14.

2. Boo NY, Jamli FM: Short duration of skin-to-skin contact: effects on growth and breastfeeding. J Paediatr Child H 2007, 43(12):831-836.

3. Gathwala G, Singh B, Balhara B: KMC facilitates mother baby attachment in low birth weight infants. Indian J Pediatr 2008, 75(1):43-47.

4. Ramanathan K, Paul VK, Deorari AK, Tanega U, George G: Kangaroo mother care in very low birth weight infants. Indian J Pediatr 2001, 68(11):1019-1023.

doi:10.1186/1471-2431-12-107

Cite this article as: Welch et al.: Correction: Family nurture intervention (FNI): methods and treatment protocol of a randomized controlled trial in the NICU. BMC Pediatrics 2012 12:107.

Submit your next manuscript to BioMed Central and take full advantage of:

- Convenient online submission

- Thorough peer review

- No space constraints or color figure charges

- Immediate publication on acceptance

- Inclusion in PubMed, CAS, Scopus and Google Scholar

- Research which is freely available for redistribution

Submit your manuscript at www.biomedcentral.com/submit

C Biomed Central 